\title{
Capitalizing on the Koran to fuel online violent radicalization: A taxonomy of Koranic references in ISIS's Dabiq
}

\author{
Thomas Frissen $^{\mathrm{a}, *}$, Erkan Toguslu ${ }^{\mathrm{b}}$, Pieter Van Ostaeyen ${ }^{\mathrm{c}}$, Leen d'Haenens ${ }^{\mathrm{a}}$ \\ ${ }^{\mathrm{a}}$ Institute for Media Studies, Faculty of Social Sciences, KU Leuven, Parkstraat 45 (PO box 3603), B-3000 Leuven, Belgium \\ ${ }^{\mathrm{b}}$ Centre for Interculturalism, Migration and Minorities, Faculty of Social Sciences, KU Leuven, Parkstraat 45 (PO box 3615 ), B-3000 Leuven, Belgium \\ ${ }^{\mathrm{c}}$ Arabic Studies Leuven, Faculty of Arts, KU Leuven, Blijde-Inkomststraat 21 (PO box 3318), B-3000 Leuven, Belgium
}

\section{A R T I C L E I N F O}

\section{Keywords:}

Online radicalization

Electronic Jihad

Dabiq

ISIS

Koran

Decontextualization

\begin{abstract}
A B S T R A C T
The current study set out to investigate to what extent ISIS is bolstering its jihadist ideology on a 'cut-and-paste' or 'cherry-picked' version of Islam in their renowned online propaganda magazine Dabiq. The main objective was to examine in a systematic and quantitative way to what extent ISIS utilizes the Koran in an atomistic, truncated and tailored manner to bolster its religious legitimacy. A total of 15 issues of Dabiq and 700 Koranic references were scrutinized. By means of a quantitative analysis we developed an innovative taxonomy of Koranic chapters and verses (i.e. surahs and ayat, respectively) on the basis of their appearance in Dabiq. Our large-scale data analysis provide consistent empirical evidence for severe decontextualization practices of the Koran in three ways: (1) a thin, Medinan-dominated religious layer, (2) ayah mutilation, and (3) clustered versus exclusive mentions. Limitations and implications for future research, policy makers and CVE initiatives are discussed.
\end{abstract}

\section{Introduction}

Words have power-especially those supposed to be coming from a 'god'-and jihadis understand that. Once again, the power of religious words has become very apparent worldwide through a number of vicious terrorist attacks inspired and justified by the "word of God' (Hassan, 2017). Internet-based communication technologies have brought about the emergence of radical virtual communities intent on preaching their own version of Islamic Gospel, laying the foundation for a global doctrine known as 'Electronic Jihad' (Rudner, 2017). This phenomenon is thought to have a multiplier effect on global jihadism, triggering both actual acts of terrorism and (online) violent radicalization (Reinares et al., 2017). ISIS is one of the key organisations waging such an Electronic Jihad, reaching and mobilizing unprecedented numbers of active supporters to its Caliphate ambition (Neumann, 2015) and interpretation of a Salafi-jihadist ideology which is more rigorist and brutal than any of its predecessors (Bunzel, 2015). As a result, both Academia and organisations set up to counter violent extremism (CVE) have shifted their attention to understanding and curtailing the online circulation of jihadist material. Surprisingly, however, the exact ideology which permeates online realms remains mostly unexplored. This study aims to bridge this gap. We set out to investigate the extent to which ISIS has been basing its jihadist ideology on a 'cutand-paste' or 'cherry picked' version of Islam (e.g. Rashid, 2017) in Dabiq, its online propaganda publication. Our main objective was to determine through systematic and quantitative analysis whether-and if so, to what extent-ISIS has been using the Koran, the most revered text in the Islamic tradition, in an atomistic, truncated and tailored manner to strengthen its religious legitimacy. We

\footnotetext{
* Corresponding author.

E-mail addresses: thomas.frissen@kuleuven.be (T. Frissen), erkan.toguslu@kuleuven.be (E. Toguslu), pieter.vanostaeyen@kuleuven.be (P. Van Ostaeyen), leen.dhaenens@kuleuven.be (L. d'Haenens).
} 
did not devote much attention to the ways ISIS propaganda is actually circulated online (cf. Gendron, 2017) or to its actual influence on its target audiences (e.g. Aly, 2016; Von Behr et al., 2013). Rather, we focused on the message, specifically its Koranic elements as ideological backbone of the jihadist doctrine.

\subsection{The Koran as terrorist recruiting tool}

So far, only a few studies have taken a systematic look at the way extremist preachers or jihad-oriented media use Islamic scripture. As part of a first qualitative analysis, Holbrook (2010) studied Koranic references in thirty Islamist propaganda documents from different time periods, including modern adaptations of medieval works (e.g. ibn Taymiyyah), Afghanistan invasion-era books (e.g. Abdullah Azzam) and post-9/11 media (i.e. As-Sahab by Al-Qaeda). The focus was on those ayat (Koranic verses) which said sources actually quoted that explicitly promote acts of violence and fighting. Holbrook's (2010) study concludes that Islamist narratives advanced by al-Qaeda and older Salafi-jihadist sources are based on a greatly de-contextualized and politically tailored interpretation of the Koran, which paradoxically violates the strict Salafist requirement of respect for the sacred texts in their most literal form. As Holbrook's findings (2010) were based on a limited sample and a mostly qualitative method focused on propaganda material from al-Qaeda, one of ISIS's major opponents, one cannot assume that ISIS communiqués follow the same Koranic referencing practices.

Rather than examining those specific Koranic verses or chapters ISIS referred to, Wagemakers (2015) studied how the organisation claims legitimacy based on Islamic traditions such as the Caliph, the Caliphate and specifically Bay'ah [the pledge of allegiance to a ruler or Caliph]. Wagemakers (2015) examined what the concept of Bay'ah to 'Caliph' Abu Bakr al-Baghdadi is to ISIS ideologues and pro-ISIS scholars, as well as how other radical Salafi jihadist critics respond to that.

A recent report by the Tony Blair Foundation (El-Badawy et al., 2015) examined references to Islamic scripture as well as various moral and traditional concepts of the jihadi ideology. El-Badawy et al. (2015) studied a much broader sample, including both AlQaeda and ISIS media sources. Here, a first attempt was made to quantify Koranic references. One finding was that Koranic citations outnumbered hadith (reports describing the words, actions, or habits of the Islamic prophet Muhammad) references or other citations of Islamic scholarship. Somewhat in line with the Holbrook's findings (2010), the most prevalent surah (i.e. chapter) appeared to be al-Baqarah in $15.6 \%$ of the cases. Furthermore, jihadis seem to refer $10 \%$ of the time to surah Āl 'Imrān, $7.2 \%$ to an-Nisā', and $6.9 \%$ to al-Anfāl. Remarkably, in contrast to Holbrook's findings, surah at-Tawbah is only referred to 5.9\% of the time.

This discrepancy could be due to the different sampling methods as well as a varying focus on either surah (i.e. chapter) or ayah (i.e. verse). Hence, our study on Koranic references will (1) examine both references at ayah and surah levels, and (2) concentrate on a single propaganda outlet by one Salafi-jihadist group only.

This brings us to this study's objective: to examine in quantitative terms whether ISIS's religious foundation is a 'cut-and-paste Islam', that is, whether it uses Islamic scriptures in an atomistic, truncated and tailored manner. Our main research question is twofold. Based on previous studies the dominant ideological and Koranic foundations of ISIS's jihadist doctrine remain underexplored. RQ1 aspires to bridge this gap in the literature:

\section{RQ1: What are the dominant Koranic references in ISIS's jihadist doctrine disseminated online?}

There is only a limited understanding of how ISIS exactly cuts, pastes and specifically merges parts of Koranic chapters to flesh out and support its Salafi jihadist ideology. Therefore we looked at the way Koranic chapters are bundled together in ISIS propaganda:

\section{RQ2: How are the different Koranic chapters related to one another, based on their co-occurrences in Dabiq?}

\section{Method}

To determine whether ISIS's ideological foundation can be said to be Islam 'per se' or just a cut-and-paste version of it, we explored the prevalence and extent of decontextualization of Koranic references in ISIS's former flagship propaganda outlet 'Dabiq'. Specifically, we concentrated on the Koranic references in fifteen issues of Dabiq. We studied (1) the frequencies of Koranic citations, i.e. surahs and ayat (respectively chapters and paragraphs/verses in the Koran), and (2) the extent to which the citations are related to one another, based on their co-appearance in Dabiq articles.

Focusing on ISIL and Dabiq is meaningful for two reasons. First, unlike other global jihadist groups, ISIS is known for its total adherence to, and uncompromising interpretation of the Salafi-jihadi ideology (Bunzel, 2015). An impressive and unprecedented online media and propaganda machine, it is also the most prevalent Salafi jihadist organization in mainstream media and on many (geo-)political agendas (Conway, 2017). In other words, investigating ISIS's strict interpretation of that ideology might reveal new patterns and insights when it comes to the use of religious texts for terroristic purposes.

Second, at the time of writing the Dabiq series was made up of exactly fifteen issues. Every publication was officially and centrally distributed through al-Hayāt Media Centre, the leading media branch of ISIS's central leadership (Winter, 2015) between July 2014 and July 2016. In September 2016 ISIS stopped publishing Dabiq, replacing it with a rebranded propaganda publication called Rumiyah (Wignell et al., 2017). This enabled us to analyze the entire Dabiq corpus. Furthermore, Dabiq remains one of the richest sources for ISIS's body of thought and ideology, especially in its glory days (Gambhir, 2014; Ingram, 2016). All issues of the publication are available online through publicly accessible websites such as Jihadology.net (Zelin, 2016) and pietervanostaeyen.com (Van Ostaeyen, 2017), both popular-science weblogs on jihadism. We focused on Koranic citations only because previous studies 
Table 1

Full corpus of Dabiq issues, title, release dates, amount of articles and words, and requency of Koranic referencing per issue, in absolute values and in proportion to the amount of words used.

\begin{tabular}{|c|c|c|c|c|c|}
\hline Issue & Title & Release date & \# articles & \# words & \# Koran citations (proportion in \%o) \\
\hline Dabiq 1: & The Return of The Khilafah & July 5, 2014 & 21 & 9838 & $9(0.915)$ \\
\hline Dabiq 2: & The Flood & July 27, 2014 & 20 & 11,704 & $14(1.196)$ \\
\hline Dabiq 3: & A Call to Hijrah & August 31, 2014 & 23 & 12,983 & $11(0.847)$ \\
\hline Dabiq 4: & The Failed Crusade & October 12, 2014 & 15 & 19,466 & $22(1.130)$ \\
\hline Dabiq 5: & Remaining and Expanding & November 22, 2014 & 16 & 12,043 & $23(1.910)$ \\
\hline Dabiq 6: & Al-Qa'idah of Waziristan: a Testimony from Within & December 30, 2014 & 13 & 26,367 & $24(0.910)$ \\
\hline Dabiq 7: & From Hypocrisy to Apostasy: The Extinction of the Grayzone & February 12, 2015 & 23 & 33,276 & $77(2.314)$ \\
\hline Dabiq 8: & Shari'ah Alone Will Rule Africa & March 30, 2015 & 19 & 28,151 & $58(2.060)$ \\
\hline Dabiq 9: & They Plot and Allah Plots & May 21, 2015 & 25 & 30,447 & $79(2.595)$ \\
\hline Dabiq 10: & The Law of Allah or the Laws of Men, & July 13, 2015 & 22 & 40,953 & $67(1.636)$ \\
\hline Dabiq 11: & From the Battle of al-Azhab to the War of Coalitions & September 9, 2015 & 24 & 32,132 & $58(1.805)$ \\
\hline Dabiq 12: & Just Terror & November 18, 2015 & 25 & 39,522 & $39(0.987)$ \\
\hline Dabiq 13: & The Rafidah: From Ibn Saba' to the Dajjal & January 19, 2016 & 18 & 29,069 & $40(1.376)$ \\
\hline Dabiq 14: & The Murtadd Brotherhood & April 13, 2016 & 15 & 35,114 & $70(1.994)$ \\
\hline Dabiq 15: & Break the Cross & July 16, 2016 & 15 & 44,977 & $109(2.423)$ \\
\hline Total $=$ & & & 294 & 406,042 & 700 \\
\hline
\end{tabular}

consistently showed that references to the Koran were more prevalent in jihadist media sources than in any other Islamic text such as the hadith or works of Islamic scholarship (El-Badawy et al., 2015; Frissen and d'Haenens, 2017).

\subsection{Corpus}

Table 1 summarises the exact corpus we used, showing the titles of the issues analyzed, the number of articles and words per issue, and the number of Koranic references, in both absolute values and in proportion of the amount of words used in each issue. As a more systematic-quantitative analysis of the matter was required, we followed a quantitative content analysis approach, combining quantitative content analysis with a social network analysis. For this, every single reference to the Koran in Dabiq was registered. Each reference represented a quote or citation from an ayah, or from a series of consecutive ayat, i.e. verses in a paragraph within a surah. This process was not limited to the registration of the specific ayat and surahs, it also enabled us to mine the verbatim textual content of the Koranic quotes throughout all issues of Dabiq.

As a result we registered a total of 23,944 words, within 700 observed in verbatim Koranic references, 579 of which were unique ayat. For the purpose of our social network analyses, all Koranic citations were aggregated from an ayah level (i.e. paragraph) to a surah-level (i.e. chapter), resulting in 72 unique surahs.

\subsection{Analyses}

Given the diverse nature of our various research questions as well as the multi-layered structure of our data (i.e. surahs and ayat), our analysis phase required a funnel model approach. This means that in two consecutive phases the analyses departed from a broad contextual exploration of the surahs towards a more detailed textual examination of the ayat quoted in Dabiq. The coding process was done in NVivo 10 for Windows and all basic statistical analyses were performed in IBM SPSS Statistics 24 for Windows. This phase included data cleaning and data aggregation. To explore a network of interrelations between the Koranic references in Dabiq, a social network analysis was performed on the aggregated textual data. For the visualization and mapping of the network, we used Gephi, an open source software package that enables network visualization (Bastian et al., 2009). Gephi is primarily used for force-directed graph drawing by means of network data transformation into a visual map (Jacomy et al., 2014), and is consistently applied in social scientific research contexts (Imani Giglou et al., 2014).

In the second phase, we broke down our data into the different ayat that are cited in Dabiq. In this phase of the study we analyzed the in verbatim texts from the Koran and the extent to which they can be contextualized historically and in ISIS's discourse.

\section{Results}

Given the varying levels of aggregation in our analysis, we will first discuss our findings on an aggregated surah level, with a focus on the dominance of the various Koran chapters and the extent to which they fit together. Furthermore, we will also devote attention to the contextualization of the referenced chapters within the broader Koranic ideological framework. Second, we will concentrate more on the ayah level as well as some of the linguistic/lexical elements of the Islamic scriptures referred to in Dabiq.

\subsection{Surah level}

At first sight, Koranic citations seem ubiquitous throughout the Dabiq series. ISIS refers to one or more ayat and/or surahs in 
Table 2

Top 10 surahs that are cited throughout all 15 Dabiq issues.

\begin{tabular}{|c|c|c|c|c|c|c|}
\hline Top 10 & Title & Place/chapter in the Koran & Period & Frequency of references in Dabiq & Proportion of Total Citations & Cumulative proportion \\
\hline 1 & At-Tawbah & Q 9 & Medinan & 76 & 10.9 & 10.9 \\
\hline 2 & Al-Baqarah & Q 2 & Medinan & 66 & 9.4 & 20.3 \\
\hline 3 & Āl 'Imrān & Q 3 & Medinan & 63 & 9.0 & 29.3 \\
\hline 4 & An-Nisā' & Q 4 & Medinan & 61 & 8.7 & 38.0 \\
\hline 5 & Al-Anfāl & Q 8 & Medinan & 42 & 6.0 & 44.0 \\
\hline 6 & Al-Mā'idah & Q 5 & Medinan & 38 & 5.4 & 49.4 \\
\hline 7 & Al-A'rāf & Q 7 & Meccan & 21 & 3.0 & 52.4 \\
\hline 8 & Al-Ahzāb & Q 33 & Medinan & 21 & 3.0 & 55.4 \\
\hline 9 & Al-An'ām & Q 6 & Meccan & 21 & 3.0 & 58.4 \\
\hline 10 & Al-Hashr & Q 59 & Medinan & 14 & 2.0 & 60.4 \\
\hline
\end{tabular}

exactly 700 instances, across all fifteen issues available online and almost 300 articles. A closer look at the data shows that Dabiq's religious foundations consist of a rather thin and fragile layer. Specifically, the 700 Koranic references amount to 23,944 words. Taking into account the total number of words in Dabiq $(n=406,042$ words), it seems that the verbatim Koranic quotes make up only $6 \%$ of the total amount of text. In addition to the great weight of such citations regardless of their frequency of occurrence, it should be noted that beside Koranic scripture ISIS refers to both hadith collections and Salafist scholars. However, the latter are subordinate to Koranic references in jihadi media outlets (e.g. Frissen and d'Haenens, 2017).

In the same vein, we might falsely conclude that the amount of Koranic references increases over time (see Table 1), and that therefore Islamic texts become increasingly prominent. However, citations appear to vary randomly from one issue to the next without a statistically significant increase over time $\left(\beta=0.090, p>.10, R^{2}=0.668\right)$. Nevertheless, as these citations are instrumental in justifying acts of inhumanity, it seems necessary to inspect the specific Koranic texts that ISIS refers to in more depth.

\subsubsection{The Koran in Dabiq}

Looking at the data at chapter level, ISIS's selection of surahs varies only ever so slightly and seems carefully thought out. More specifically, we found that a little under $50 \%$ of all Koranic citations refer to specific 6 surahs only (see Table 2).

Going into further detail, the majority of the surahs cited (68,73\%) refer to 'Medinan' chapters of the Koran. These are surahs believed to have been revealed by Allah after the Prophet Muhammad had performed his Hijra from Mecca to Medina (i.e. the exodus of the Prophet Muhammad and the Muslims to Medina in order to escape persecution in Mecca (Maher, 2016, p. 39)). The surahs and ayat 'revealed' to the Prophet in Mecca are known as 'Meccan'. A small selection of surahs is compiled with both Meccan and Medinan ayat. According to a Western classification of the Koran, i.e. Nöldeke's Chronology of the Koran (Donner, 2011), 24 out of the 114 Koran chapters are Medinan, with most of the Koran 'revealed' in the Meccan period. In general, much of the material at the end of the Koran is from the Meccan era, whereas several of the long surahs at the beginning are from the Medinan era. This is important, given the fact that the surahs and verses that came to the Prophet in the Medinan period are fundamentally different from the surahs from the Meccan period. It is self-evident that during the Meccan period the Koran introduced to a small community the basic belief system of Islam, with themes such as the existence of 'God', the 'unity of God', the 'People of the Book' (Ahl Kitab), the prophethood of Muhammad, and the belief in resurrection after death (Abdel Haleem, 2005: xvii-xviii). However, after the Hijrah, and thus during the Medinan period, other subjects will be added. Medinan surahs deal more with (1) civil, criminal and international law, (2) the command to fight enemies, and (3) jihad rulings (Holbrook, 2010).

Since we wanted to determine which of these Koranic passages are favoured by ISIS, we focused on actual quotes, as well as any missing parts in any quoted surah. In general, the Koran consists of 114 unique surahs divided into 6236 verses or ayat (Bergsträßer and Pretzl, 1926; Nöldeke, 1860). As mentioned above, Dabiq cited 72 different surahs and 579 unique verses. Taking the verses as a reference, this means that a mere $9.28 \%$ of the complete Koran is used as a religious foundation in Dabiq's discourse. In other words, roughly more than $90 \%$ of the Koran texts do not enter into ISIS's version of Islam. The Dabiq editors tend to mostly quote the first half of the Koran, more specifically the first ten chapters (see also Table 2), which are predominantly Medinan. Aiming to visualize ISIS's selective Koranic referencing, Fig. 1 shows all the surahs in the Koran and the frequency in which they appear in Dabiq.

The graph clearly demonstrates that the distribution of the surahs that are structurally paraphrased in Dabiq is strongly skewed to the left or to the first set of chapters in the Koran. Given this indication of selectivity, we wanted to see which surahs attract the most attention and the extent to which they cluster together. We therefore performed a network analysis.

\subsubsection{Network analysis of the surahs}

For this part of the study we used the Gephi open-source software package, version 0.9.1 (Bastian et al., 2009). For our analysis, we specifically wanted to investigate how one Koran citation relates to another, given their co-occurrence in Dabiq articles. A first step is to create an adjacency matrix that enables us to summarize relationship data in a symmetric network for the identification of corresponding data elements. Since we are only focusing on relationships and co-appearance and not on ties with directed associations, we will treat the relations in our data as undirected. Then, Gephi will translate the adjacency matrix into its primary data elements which are the actors, called 'nodes', and ties, called 'edges'. Together these nodes and edges are used to build up a 'system', or a network of relations. In our case, we created a network of surah quotes in which every surah becomes a node and every 


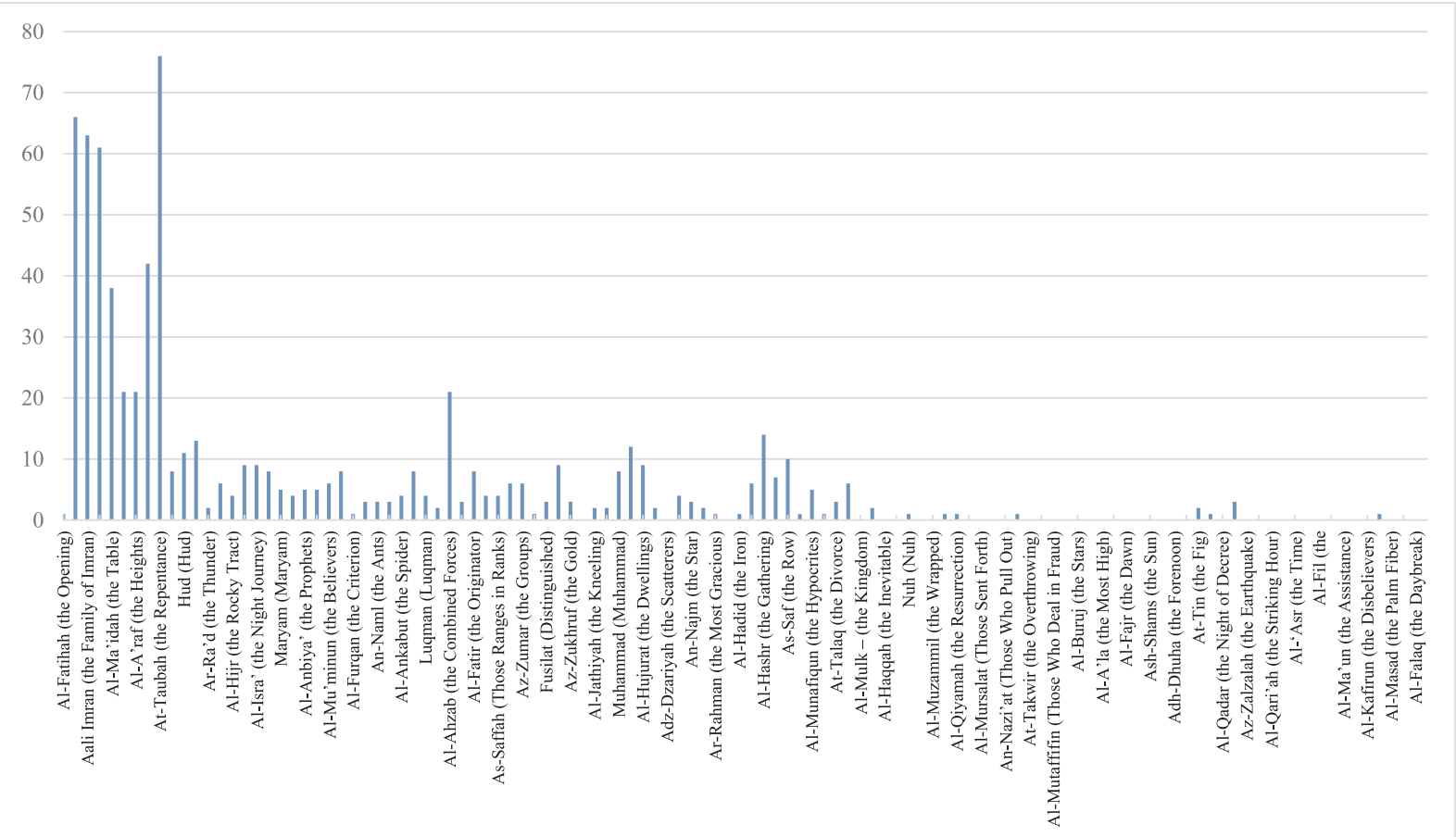

Fig. 1. Histogram with all Koranic referencing in Dabiq. The vertical axis represents the frequency in which a specific surah is found in the data. On the horizontal axis, the full Koran is plotted. Note: Not all 114 surahs are mentioned by name. However, every tick mark represents one surah.

interconnection between the surahs becomes an edge. All edges will be weighted according to the frequency in which some surahs are appearing together, i.e. the more often two surahs appear together, the stronger the edge will be in the system. After filtering out noisy data and the not-connected nodes in the network, Gephi identified 71 nodes, each corresponding to one unique surah, and 918 edges.

For the lay-out of our network we used the Force Atlas 2 algorithm which is the default lay-out algorithm in Gephi (Jacomy et al., 2014). Just like other force-directed algorithms, e.g. Fruchterman-Reingold (Fruchterman and Reingold, 1991), Force Atlas 2 aims to simulate a 'real life' physical system in which nodes that are interconnected are drawn as closely as possible to each other, while at the same time, the edges should overlap each other as little as possible. Additionally, for the visualization of our final network model, we used the LinLog mode. In this mode, Gephi lays out a network structure according to the Force Atlas 2 algorithm but places the nodes in the most readable positions (Jacomy et al., 2014). For this, the placement of the nodes is dependent on the community structure of the network. In other words, nodes that hold stronger associations are gravitating more closely to one another. Fig. 2 shows the network graph of interrelated surahs in Dabiq.

This analysis let us examine which surahs are the most central in the network as well as any interconnection between them. To do so we needed (1) to mark every node's importance in the total system by measuring its degree centrality, and (2) to cluster groups of strongly related nodes together into different communities, using modularity statistics.

3.1.2.1. The most central surahs in Dabiq. Degree centrality let us determine the size of each node based on its number of connections (i.e. edges) with other nodes in the network. Since we study co-occurrences, our graph is undirected and therefore the in-degree and out-degree measures are equal. Based on degree centrality, sizes vary according to the number of edges: the more edges a node possesses, the higher its centrality in the network, and accordingly, the larger its size. Here larger surah nodes in the graph are the most central vertices in the network as they have the most connections with other surahs in Dabiq. As can be seen in our network (Fig. 2), the surahs with the highest degree centrality in the network are al-Baqarah, an-Nisā', and at-Tawbah, and Āl 'Imrān.

3.1.2.1.1. Surah al-Baqarah. On closer scrutiny it appears that the node in the network with the highest degree of connections is surah al-Baqarah (Q2; translation: 'The Cow'). Surah al-Baqarah is the second most cited Koran chapter in Dabiq, (after at-Tawbah), but it is the most central surah in the network, co-appearing with other surahs in 60 instances. As already pointed out by El-Badawy et al. (2015), al-Baqarah is an essential justification instrument in many jihadi propaganda outlets. In Islam, al-Baqarah is one of the most important surahs given its extensive discussion of other religions, as labelled in the Koran as the 'People of the Book'. This matter is mainly discussed from a theological perspective, with themes such as the duration of one's stay in Hell and the status of angels. The important rituals mentioned in this surah include the Mecca pilgrimage, Ramadan, and the direction towards Mecca. For Salafi jihadists this surah stands among the most inclusive chapters in the Koran, as it deals with practices they might view as representing 'pure Islam', such as monotheism, life after death, the stance towards 'Jews and hypocrites', and jihad (Ayatullah Kamal 


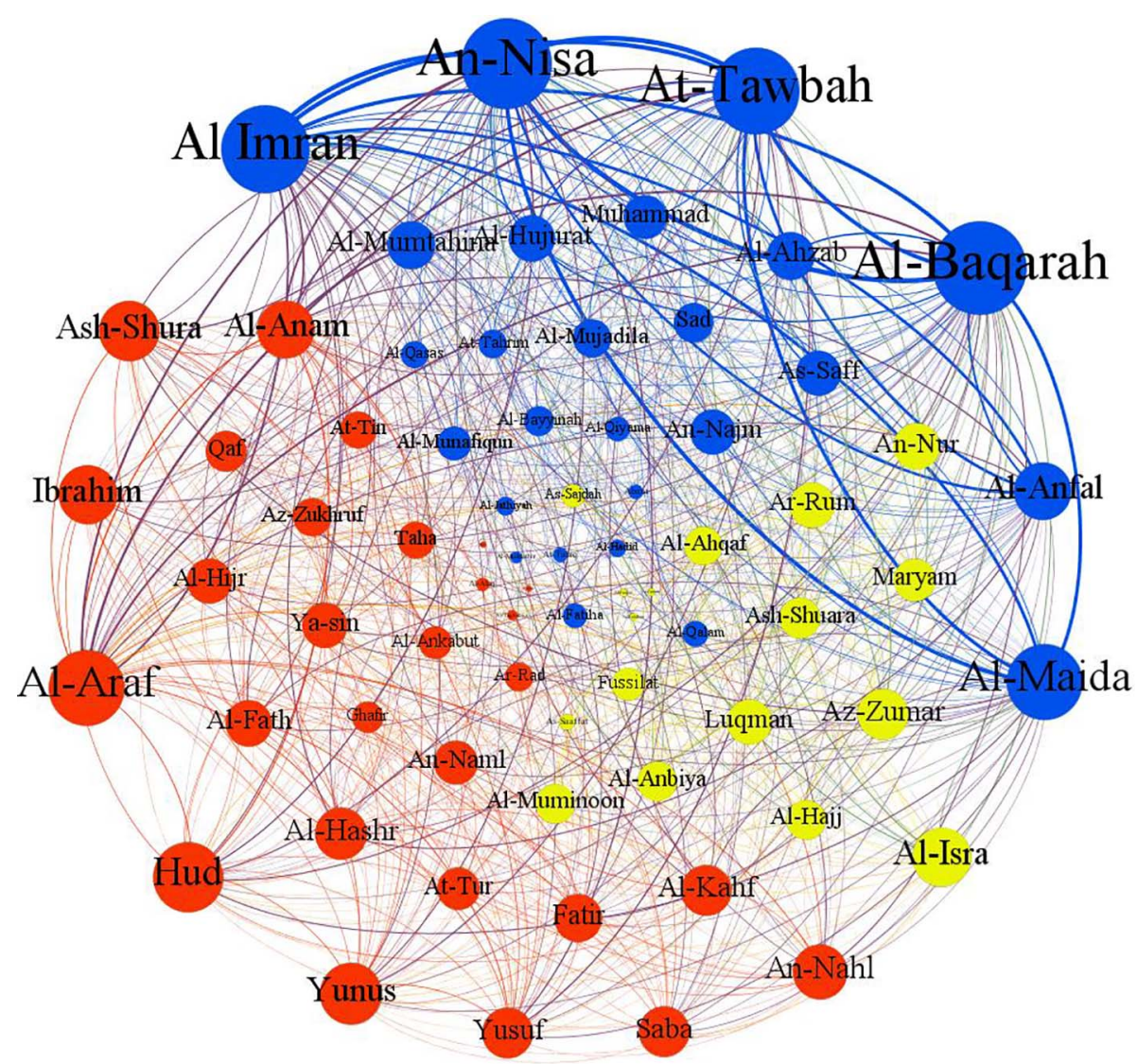

Fig. 2. Network graph of interrelated Sūrah references in ISIL's Dabiq magazine. Size of the nodes varies according to their degree centrality. The color indicates the communities according to the modularity class.

\section{Al-hajj Sayyid Imani, 1991a).}

Despite the richness of different topics in al-Baqarah, the few verses that deal with fighting are the ones ISIS cites most frequently. Ayat 194 and 217 are among the al-Baqarah ayat to be found in Dabiq-they both appear three times. These are verses that discuss a legal framework in which fighting may be socially and morally acceptable. In addition, they tend to be quoted in abstract debate to legitimize acts of killing as an answer to oppression, which is more in line with their historical meaning (for an extensive discussion, see Lawrence, 2017, for instance). Thus in the feature piece in issue 7 of Dabiq, 'The Extinction of the Grayzone', al-Baqarah: 217 is used to justify the existence of the Caliphate and the mujahidin's suicidal, violent operations against 'the Crusaders' and 'the West', who-in ISIS's eyes-oppress Muslims in the Middle East.

Furthermore, Dabiq's editors cited al-Baqarah mainly in combination with other Koranic chapters (in 60 out 66 cases (90.9\%)). As can be seen in Fig. 2, not only does al-Baqarah have many fine edges in common with smaller nodes in the network, it also has stronger ties with the other top-ten surahs, such as at-Tawbah, Āl 'Imrān, and an-Nisā'. The connection appears to be the strongest with this latter surah. More concretely, our data shows that an-Nisā' and al-Baqarah appear alongside each other in twenty-one occasions. In other words, for every three references to al-Baqarah, the Dabiq team also refers to surah an-Nisā'. To explain this we need to take a closer look at the specific parts of this surah that are actually quoted.

3.1.2.1.2. Surah an-Nisā'. Just like surah al-Baqarah, surah an-Nisā' ('The Women'), deals with a broad diversity of topics. AnNisā' is one of the fundamental surahs for Islamic jurisprudence because of the extensive attention it devotes to legislative aspects. Additionally, the surah deals with the topic of war and peace and provides specific information on how Muslims should act during both. As in many of the other Medinan surahs, such as in An-Nisā', the 'People of the Book' and 'hypocrites' are largely covered. For instance one of the topics in this surah is Islam's view of Christianity, specifically the crucifixion of Jesus Christ (Q4: 157), which is also discussed in the ISIS publication (Issue 5, 'Yahya: Lessons From A Shahid', p. 4). In Dabiq, the most frequent an-Nisā' citations refer to those parts of the chapter that pertain to vigilance and defence against 'Jews and hypocrites'. Based on our data, 37.7\% of all anNisā' quotes in Dabiq refers to ayat 73-100 and 24.6\% to ayat 136-175. According to Maududi's tafsir (exegesis) (2006), these two groups of ayat are meant to encourage Muslims to fight for the cause of Islam.

3.1.2.1.3. Surah at-Tawbah. The most cited surah in Dabiq (with fewer connections to other surahs in the network) is at-Tawbah ('Repentance'). This Medinan surah mostly includes verses on topics such as (1) the conduct of war, (2) the relationship with opponents during peacetime, and (3) the fight against 'idolatrous Arabs' and the 'People of the Book'. All of these topics are recurrent 
themes in Dabiq. Another explanation why Dabiq regularly quotes at-Tawba is the presence of the ayat on jihad as well as others dealing with legal issues in relation with warfare, such as the 'ayah of the sword' (Q9: 5), the most cited at-Tawbah verse. We discuss this ayah in more detail below.

3.1.2.1.4. Other surahs. Finally, not all top-ten surahs are equally connected, i.e. equally central network components. For instance, despite the fact that surahs such as al-Hashr (Q59; 'The Exile') or al-Anfāl (Q8; 'The Bounties', or 'Spoils of War') are among the most cited in Dabiq, they are connected with other vertices in the network to a limited extent only. In other words visualization of the data shows that ISIS has a clear tendency to cite a subset of the more prevalent surahs rather in isolation. Or else, when cited in combination, they are flanked by only a small group of other surahs. A good illustration of this can be found in the differences between the uses of surah al-Anfāl (Q8) and of surah Hūd (Q11; 'Hūd' [name of the prophet]). Whereas al-Anfāl (Q8) appears in Dabiq forty-two times, Hūd is only cited eleven times. In the network, however, it can be clearly seen that surah Hūd (Q11) has a larger node and thus has a higher degree centrality than al-Anfāl. This suggests that a frequently cited surah such as al-Anfāl can be the only Koranic reference in a given Dabiq article, without being surrounded by other surahs. In contrast, surah Hūd is cited four times less frequently, but, when cited, it is alongside other Koranic references. In the context of our central research question, this finding is important. However, an analysis on a more detailed ayah level is necessary in order to learn why some surahs, such as al-Anfāl, are more likely to be mentioned exclusively.

3.1.2.2. Clusters of surahs in Dabiq. In order to develop an in-depth understanding of groups of surahs that are more strongly related to one another, we identified the various communities in the network with different colours. To differentiate clusters we used the modularity class tool in Gephi. Modularity is a method based on the concept of collective proximity to structure (or cluster) the data into communities (Jacomy et al., 2014). Following the modularity algorithm, a community is composed when the modularity, or the collective proximity, of the relations between the nodes within a group is higher than the modularity outside of the group (for a more extensive discussion, see Newman, 2006)). As can be seen in Fig. 2, we were able to identify in our surah network three significant clusters that can be roughly organized as (1) central, strongly interconnected surahs from the Meccan period, (2) central, strongly interconnected surahs from the Medinan era, and (3) more isolated surahs from either one of these two periods.

3.1.2.2.1. Meccan surah cluster. First, we identified the red community, labelled as the 'Meccan cluster' (40,28\% of the nodes) because a majority of the dominant surahs in this cluster are from the Meccan era. This cluster is overwhelmingly composed of surahs that refer to several Islamic prophets such as Hūd (Q11; 'Hūd'), Ibrahim (Q14; 'Abraham'), Yunus (Q10; 'Jonah'), Yusuf (Q12; 'Joseph') and, in the smaller nodes, Nuh (Q71; 'Noah'). However, the most central node in this cluster-al-Ar'af (Q7; 'The Heights'), with 21 appearances in Dabiq-does not explicitly refer to a Prophet. Nevertheless, a closer inspection of the topics within this surah shows that this finding is logically explainable. The main theme in surah al-Ar'af is considered as a message from 'God'-specifically a warning to those who might reject it (Maududi, 2006). The surah's main theme is about obeying the messenger(s) of 'God'. Many verses in this chapter deal with events and the lives of many well-known prophets, such as Nuh and Hūd.

3.1.2.2.2. Medinan surah cluster. Second, the modularity algorithm identified the blue community, or the 'Medinan cluster' (36,11\% of the nodes). In contrast to the red cluster, nearly all central surahs in this cluster are 'revealed' to the Prophet in the Medinan era. In this group, the most frequently quoted surahs in Dabiq, i.e. al-Baqarah, at-Tawbah, an-Nisā' and Āl 'Imrān cluster together in this group. We found two main reasons of Dabiq's preference for these Medinan surahs and why they are tied together in this cluster.

First, these Medinan surahs are complementary to each other given the similarity of the topics they deal with. This is specifically the case for their attention devoted to other religions, such as Judaism and Christianity, also called the 'People of the Book'. AlBaqarah is one of the most important surahs considering this topic with its extensive discussion of the history of the 'Children of Israel'. Similarly, surah Āl 'Imrān deals with the history of the Christians, such as the birth of Jesus Christ, his 'miracles', and his relationship with the apostles. Surah al-Mā'idah discusses the normalization of relations with the 'People of the Book', for instance intermarriage and treaties. Lastly, surah an-Nisā' introduces a new category called the 'hypocrites' (munafiqun) and devotes a great deal attention to Muslims' relations with this group. Consequently, these typical Medinan topics, such as the stance towards the 'People of the Book', the 'Children of Israel' and the munafiqun are very present in all Dabiq issues.

Second, these surahs contain various rituals and legal prescriptions concerning the pilgrimage, lawful foods, intermarriage, ritual purity, family relations, and moral issues of cowardice, hypocrisy and worldly attachment. In almost every single article, using Koranic references, Dabiq refers to moral issues pertaining to cowardice and worldly attachment as well as 'God's reward and trust.

Nonetheless, even though this cluster is marked by a rich diversity of fundamental ideological and spiritual concepts, the passages on international relations, the 'rules of engagement' in the context of battles (mostly against non-Muslims) appear to be the main reason why these surahs are tied to one another and to other, less central nodes, such as al-Anfāl, al-Ahzāb or al-Munāfiqūn.

3.1.2.2.3. Cluster of less prevalent surahs. Third, the yellow community $(23.61 \%$ of the nodes-the 'cluster of less prevalent surahs') includes those surahs that are less frequently cited in Dabiq and are more weakly connected to other surahs. These are surahs from the Medinan and the Meccan period, with the latter slightly outnumbering the former. Rather than the period of origin, this cluster is marked by the fact that these surahs are less prevalent in Dabiq, and therefore also less connected with other nodes in the network. The nodes that are more connected in this cluster, such as al-Isra, az-Zumar, and al-Hajj, appear in Dabiq writings equally along both Medinan and Meccan surahs.

\subsection{Ayah level}

To better understand why some of the surahs are so dominant and how they are clustered together, we need to take a closer look 
Table 3

Summary of the most-quoted ayat in Dabiq. Only showing here those ayat that are cited five times or more.

\begin{tabular}{|c|c|c|c|c|c|}
\hline & Surah & Place/chapter in the Koran & Ayah & Period & Frequency \\
\hline 1 & Al-Anfāl & Q 8 & 39 & Medinan & 12 \\
\hline 2 & Al-Mā'idah & Q 5 & 51 & Medinan & 11 \\
\hline 3 & Al-Hashr & Q 59 & 14 & Medinan & 9 \\
\hline 4 & At-Tawbah & Q 9 & 5 & Medinan & 9 \\
\hline 5 & Āl ‘Imrān & Q 3 & 103 & Medinan & 8 \\
\hline 6 & Al-Anfāl & Q 8 & 73 & Medinan & 6 \\
\hline 7 & Al-Mā'idah & Q 5 & 54 & Medinan & 5 \\
\hline 8 & Al-Mujādila & Q 58 & 22 & Medinan & 5 \\
\hline 9 & An-Nisā' & Q 4 & 76 & Medinan & 5 \\
\hline 10 & An-Nisā' & Q 59 & 97 & Medinan & 5 \\
\hline 11 & At-Tawbah & Q 9 & 123 & Medinan & 5 \\
\hline 12 & At-Tawbah & Q 9 & 24 & Medinan & 5 \\
\hline 13 & Fātir & Q 35 & 43 & Meccan & 5 \\
\hline 14 & Yūsuf & Q 12 & 21 & Meccan & 5 \\
\hline
\end{tabular}

at the texts actually quoted by ISIS. For this we will examine those ayat (verses) quoted structurally, i.e. more than five times (see Table 3).

First, as can be seen in Table 3, some of the findings from our surah analysis differ from our ayah analysis. Whereas al-Baqarah was the second most cited surah and the most centrally connected vertex in the network, it does not at all appear in the table with frequently cited ayat. The most cited al-Baqarah verses appeared only a maximum of three times in Dabiq. As our cut-off point for the ayah-analysis is a minimum of five citations, al-Baqarah does not appear on the list above, indicating that it has a broader diversity of rather fewer ayat references. The top-three most frequently cited ayah in Dabiq, however, belong to al-Anfāl 39 (Q8: 39), al-Mā'idah 51 (Q5: 51) and al-Hashr 14 (Q59: 14). We focus particularly on al-Anfāl 39, given its dominance in the Dabiq narratives. With twelve citations, it is the most cited ayah. This ayah is 'revealed' to the Prophet shortly after the battle of Badr, which is regarded as one of the first major confrontations between Muslims and non-Muslims (Ayatullah Kamal Al-hajj Sayyid Imani, 1991b). Since they were strongly outnumbered by their Meccan opponents, a victory for the Muslims seemed unlikely. However, through 'divine intervention'-'through God's Will only' (see Q3: 123), the Muslims were able to defeat their enemies with few losses. After the battle, and in a state of euphoria, Muhammad turns to 'God' for guidance and ayah al-Anfāl 39 is 'revealed'.

'And fight them until there is no fitnah [rebellion] and [until] the religion [i.e., worship], all of it, is for Allah. And if they cease - then indeed, Allah is Seeing of what they do., ${ }^{1}$

(al-Anfāl, Q8:39)

In this verse Allah tells Muhammad and his followers to continue their military campaign. In Islam, as described in several tafsir (e.g. Ayatullah Kamal Al-hajj Sayyid Imani, 1991b), the objective of a military campaign has never been to occupy new land, only to spread the word of Allah. Interestingly, this is exactly ISIS's interpretation of this ayah. For instance, in Dabiq's issue nr. 10, the feature piece 'The Law of Allah or the Laws of Men' of mentions this ayah more than five times to legitimize and emphasize the idea that fighting is a religious obligation.

'[...] the obligation to fight the resistant parties, 'This is because Allah said in His book, \{And fight them until there is no fitnah and [until] the religion, all of it, is for Allah\} [Al-Anfäl: 39]. So, if some of the religion is for Allah and some of it is for other than Allah it becomes obligatory to fight them until the religion is for Allah alone'.

Diving a bit deeper into Dabiq and the contexts in which this verse is referred to, we see that it could indeed have been selected for religiously reasons, but that historical and geopolitical elements are at play as well.

Shaykh Abū Mus'ab az-Zarqāwī (rahimahullāh) said, 'We do not perform jihād here for a fistful of dirt or an illusory border drawn up by Sykes and Picot. Similarly, we do not perform jihād for a Western tāghūt to take the place of an Arab tāghüt. Rather our jihād is loftier and more superior. We perform jihād so that Allah's word becomes supreme and that the religion becomes completely for Allah. \{And fight them until there is no fitnah and [until] the religion, all of it, is for Allah\} [Al-Anfäl: 39].

(Dabiq issue 8; 'Foreword')

Here the Dabiq editors quote ISIS founding father Abu Musab az-Zarqawi (Atwan, 2015)—whose objectives were undoubtedly religious-emphasizing their point with a reference to al-Anfāl. However, by attacking and therefore emphasizing the Sykes-Picot agreement and 'Western țawägit [false rulers]', Abu Musab hints at implicit (territorial) ISIS goals as well. In that sense, this may show that ISIS is not be motivated by religion alone. There may be (geo-)political concerns, even though the overarching approach and objective is to "perform jihād so that Allah's word becomes supreme and that the religion becomes completely for Allah". This then also explains the dominance of both al-Mā'idah 51 and al-Hashr 14, two verses that call for being vigilant towards the enemies of Islam and interrelations among them.

\footnotetext{
${ }^{1}$ For all Koranic references in this study we used the official English translation as published by Saheeh International (2004)
} 
Second, more in line with our findings at surah level, a majority of the most cited ayah in Table 3 is from surah at-Tawbah (Q9) (translation: 'The Repentance'). On the face of it this might not be all too surprising, as it is known that at-Tawbah (Q9) is one of the most influential Islamic scriptures for opponents of jihad (Lawrence, 2017), and has been found to be a recurring reference in different types of jihadi communiqués (El-Badawy et al., 2015). Also, about $11 \%$ of all Koranic citations in Dabiq, pertain to this surah $(n=76)$. A more detailed inspection of the surah in the Koran and the way it is represented in Dabiq gives further evidence that ISIS's ideology may be based on a cut-and-paste version of Islam. In the Koran, at-Tawbah (Q9) consists of 129 verses. In Dabiq, we came across 42 references to unique at-Tawbah (Q9) verses. In other words, for every three at-Tawbah (Q9) verses in the Koran, ISIS refers to only one ayah. Furthermore, it seems that Dabiq picks its Koranic references very carefully. In Dabiq, ayah 5 appeared to be the most cited at-Tawbah (Q9) verse with 9 citations. The controversy about this verse (Q9:5)—sometimes referred to as the 'ayah of the Sword'-is explained by the fact that it calls for sacrificial violence against non-Muslims (Meyer, 2017) and for war against polytheists and 'idolaters' (Abdul-Rahman, 2009; Maher, 2016).

'And when the sacred months have passed, then kill the polytheists wherever you find them and capture them and besiege them and sit in wait for them at every place of ambush. But if they should repent, establish prayer, and give zakah, let them [go] on their way. Indeed, Allah is Forgiving and Merciful'.

(Surah at-Tawbah, Q9:5)

Dabiq mostly refers to a specific sentence or a carefully chosen snippet, only quoting the full verse in a few instances

'And when the sacred months have passed, then kill the mushrikin wherever you find them'.

(Dabiq 7, p. 20)

'Then kill the mushrikin wherever you find them'.

(Dabiq 13, p.8)

'Then kill the pagans wherever you find them'.

(Dabiq 15, p.63)

It cannot be denied that ISIS favours the most violent sentence of the verse, leaving out the rest. Of course, such selective use is not new (e.g. Holbrook, 2010). But it is worth noting that independent of empirical proof in terms of selective and decontextualized referencing, the data further reveals that interpretation of the verse by ISIS is not necessarily in line with alternative Salafist interpretations. A meaningful example for this can be found in the following quote, where the Dabiq authors clearly state who they consider to be 'them' in Q9: 5:

'Know well that our fight will continue until you are defeated and submit to the rule of your Creator, or until we achieve martyrdom. Allah has made our mission to wage war against disbelief until it ceases to exist, as he has ordered us to kill all pagans wherever they are found'.

(Dabiq 15, p. 63)

In ISIS's interpretation, 'them' equates all 'disbelievers'-all non-Muslims, or everybody within the 'People of the Book' category, i.e. Jews and Christians. However, both Islamic scholars have argued that this call for slaughter is too broad and that the historical context should be taken into account. According to former Islamist scholar Rashid Rida, and in sharp contrast to ISIS' interpretation, the 'them' in at-Tawbah does not refer to non-Muslims but only to historical opponents who betrayed Muslims by breaking a peace treaty and warring against them (Fachrodin, 2015). In other words ISIS's selective use of these verses is not representative of the whole Koranic statement about the 'People of the Book' or relations with non-believers.

Furthermore, from a linguistic perspective and concerning Dabiq's actual readership, a meaningful element in the above Dabiq quote (Q9:5) should be highlighted here. Research on audiences of online terrorist propaganda states that jihadist media outlets such as Dabiq are used as recruitment tools, targeting young and vulnerable individuals (Aly, 2016). However, other scholars argue that Dabiq is no more than a costly PR exercise (see for example Novenario, 2016), solely and squarely aimed at political opponents in the West. The abovementioned quote seems to bear this out. Word such as 'our fight', 'you' and 'we' clearly show authors are aware of their readers' Western background. In other words Dabiq may not be meant to address supporters but to impress and intimidate opponents. Here, the article's title ('Breaking the Cross') clearly targets 'Christians' or 'crusaders'-in other words, Western nations.

\section{Discussion and conclusions}

Internet-based communication technologies have brought about the emergence of radical virtual communities intent on spreading a modified and truncated version of the Koran, laying the foundation for 'Electronic Jihad' (Rudner, 2017). ISIS is one of the key organisations waging such an Electronic Jihad, reaching and mobilizing unprecedented numbers of active supporters of its Caliphate ambition and interpretation of a salafist jihadist ideology more rigorist and brutal than any of its predecessors. This study set out to investigate the validity of assumptions positing that ISIS has been basing its jihadist ideology on a 'cut-and-paste' or 'cherry picked' version of Islam. Our analyses show that this may indeed be the case. Empirical and quantitative analyses let us develop a taxonomy of Koranic chapters (i.e. surahs) based on their recurrence in Dabiq. We argue that this study's findings make a noteworthy contribution to the current state of the art through three conclusions: ISIS propaganda in Dabiq is based on (1) a thin, Medinandominated religious layer, (2) de-contextualization and 'ayah mutilation', and (3) clustered versus exclusive mentions. 


\subsection{Thin, Medinan-dominated religious layer}

Our data validate an assumption found in previous studies by Holbrook (2010) and El-Badawy et al. (2015)—that ISIS makes extensive Koranic references-while showing a need to concentrate on both levels of analysis (i.e. single ayah level and aggregated surah level). Looking at surah level only, in line with El-Badawy et al. (2015), we would inadequately conclude that ISIS refers to a broad part of the Koran, by citing 72 of the 114 unique chapters in the Koran. However, after zooming in on the different ayat cited in Dabiq, a much more nuanced picture comes to the fore. Out of 6236 ayat in the Koran, Dabiq mentions no more than 579 . In other words, less than $10 \%$ of the Koran feeds into ISIS's discourse in Dabiq. Our analyses show that this small selection mostly pertain to fighting for the cause of Allah as well as relations between Muslims and non-Muslims. One might argue that this is a rather limited connection with Islam-religious concerns only a thin layer in ISIS's salafist jihadist doctrine.

A similar trend was found regarding references to Medinan surahs versus Meccan surahs, with the former significantly outnumbering the latter. While a majority of the surahs in the Koran were 'revealed' to the Prophet in the Meccan period, ISIS seems to strongly favour Medinan surahs rather than Meccan ones-(1) civil, criminal and international law, (2) the command to fight enemies, and (3) jihad rulings (Holbrook, 2010). It is said (Maher, 2016) that Medinan surahs tend to be more forceful, which sheds a specific light on a finding based on our network analysis clusters: in Dabiq, Medinan surahs are flanked by other Medinan surahs rather than Meccan surahs, and vice versa. This once again highlights a selective and narrow use of Koranic passages, possibly functioning as echo chambers to one another.

These findings seem particularly important for 'countering violent extremism' (CVE) initiatives that aim to develop counternarratives. Given the fact that ISIS and its supporters are mostly susceptible to Medinan themes and surahs, we would encourage CVE programs to come up with counter narratives that are also grounded in Medinan surahs, matching ISIS's religious and ideological style, language and vigour (cf. Hassan, 2017).

\subsection{De-contextualization and 'ayah mutilation'}

ISIS seems to structurally decontextualize Koranic references. This is not entirely new or surprising, although our analyses show Koranic de-contextualization occurs on at least three levels. First, the context of early Islam. That time in which the key foundations of the religion—including the unity of 'God' (Tawhid)—were laid out (the thirteen years of Meccan revelations (Abdel Haleem, 2001: $5)$ ) is structurally neglected by using surahs that were mostly 'revealed' in the Medinan period. Second, the most cited Koranic chapters in Dabiq—surah at-Tawbah (Q9), surah al-Baqarah (Q2), surah Āl 'Imrān (Q3), surah an-Nisā' (Q4)—are known for their richness and extensive discussions of many different religious traditions. However, ISIS decontextualizes these surahs by distilling only those parts that deal with warfare, believer-disbeliever relations, and the rules of engagement. Third, in most cases the ayat quoted are truncated and abridged-a practice we might call ayah mutilation. A striking example is the 'ayah of the Sword' (atTawbah, Q9: 5), which ISIS indeed butchers, exclusively focusing on the command to kill: 'Then kill the mushrikin [polytheists] wherever you find them'. In other words not only does Dabiq neglect the command to wait until 'the sacred months have passed' that precedes this passage-it also cuts out the following one that calls for 'leniency and goodwill' towards enemies: 'But if they should repent, establish prayer, and give zakah, let them [go] on their way. Indeed, Allah is Forgiving and Merciful'. Dabiq also tends to conflate historical and contemporary foes, falsely equating the 'them' in at-Tawbah with non-Muslims in general. However, as Fachrodin argues (Fachrodin, 2015), the 'them' in this verse should be strictly interpreted according to its historical meaning: those Meccan opponents that actively sought to persecute Muslims.

This second conclusion has important implications on two counts. First, CVE initiatives should invest in programs aiming to guarantee that ISIS and jihad supporters are aware of this phenomenon of 'ayah mutilation' and Koranic de-contextualization, since it breaks the strict salafist principle of literal Koranic interpretation. Successfully implemented, this strategy could diminish the influence of the ideological factor in (online) violent radicalization processes (cfr. Hafez and Mullins, 2015). Second, the same atomistic reading of the same $10 \%$ Koranic verses can be found in the rhetoric of a number of Western critics and politicians intent on advancing populist and anti-Muslim agendas (Fachrodin, 2015). Both CVE initiatives and the mainstream media can play an major role by putting the 'mutilated' verses back in context and shifting attention to the vast majority of Koranic texts that do not promote violence. It seems reasonable to assume that this could reduce anti-Muslim sentiment in Western societies (Ciftci, 2012).

\subsection{Clustered vs. exclusive mentions}

Lastly, as seen in the co-occurrence network, the most frequently cited surahs tend to be flanked by at least one reference to another surah. Our analysis highlights three clusters of frequently co-occurring Koranic references-which does not mean that the most cited surah are also the most-networked ones. A case in point here is the al-Anfāl surah (Q8). While it is among the mostfrequently cited surahs in Dabiq, our network analysis shows it does not stand among the most networked ones. This can be explained by zooming in at ayah level. We found that the most frequently cited ayat were not necessarily in line with the most frequently cited surahs. While surah al-Anfāl was only fifth in line of the most cited surah, ayah al-Anfāl 39 was the most prevalent Koranic reference in Dabiq. This suggests that frequently cited surahs such as al-Anfāl, and specifically ayah al-Anfāl 39 can be used exclusively and as the only reference to the Koran in a given Dabiq article. This seems to be in contrast with surahs that appear more embedded in a broader religious referencing pattern. Nevertheless, the fact that some ayat-for instance al-Anfāl 39-are the only religious references in a vast amount of Dabiq articles demonstrates that ISIS tends to use very specific fragments of the Koran. In other words, it seems safe to conclude that ISIS deliberately cuts and pastes and even 'mutilates' the Koranic message to tailor it to its own. 


\subsection{Limitations and directions for future research}

In this study we limited our scope in several ways. First, we studied only ISIS's references to the Koran. We do acknowledge that this approach has its limitations as classical Koranic exegesis states that correct interpretation of the Koranic message requires studying intertextuality with the hadith (Ayatullah Kamal Al-hajj Sayyid Imani, 1991a; Fachrodin, 2015). We also acknowledge that the political tone of Dabiq's pieces-for which the hadith and other works of Islamic scholarship are also fundamental resources-may demand that a broader palette of Islamic scriptures be taken into account. For instance most political cleavages in Dabiq (such as conflicts with other major Islamist groups or schools of Islamic jurisprudence) are expressed by reference to both Koranic sources and hadith collections, underlining the assumption that Koranic exegesis and hadith interpretation are inseparable entities. However, we chose not to look at the interrelation between hadith and Koran in Dabiq, because (1) the hadith are considered a secondary source for Islamic teachings (Fachrodin, 2015), and (2) previous studies consistently showed that the hadith are far less present in ISIS's discourses than the Koran (El-Badawy et al., 2015; Frissen and d'Haenens, 2017). Of course, future studies may be justified in investigating the interrelations between all Islamic quotes in salafist jihadist communiqués.

Furthermore, at the time of analysis, ISIS's media centre replaced the Dabiq propaganda publication series with a new one it called Rumiyah ('Rome') (Wignell et al., 2017). While Wignell et al. (2017) argue there are few fundamental differences between the two publication series, we limited our sample to the fifteen Dabiq issues, as Dabiq is still viewed as one of the richest information sources on ISIS's body of thought and ideology, as it dates back to its glory days (Gambhir, 2014; Ingram, 2016; Novenario, 2016). This publication received significant scientific attention and has been seen as an essential platform for charismatic preachers to call for jihad (Gendron, 2017). Dabiq is held partly responsible for the recruitment, mobilization, and radicalization of English-speaking Islamist sympathizers (Europol, 2016; Feddes et al., 2015)—amply justifying any decision to study it. Nevertheless, we cannot generalize and extrapolate our findings to salafist jihadist thought in general.

Last, we encourage future researchers to shift their attention from salafist jihadist communiqués to anti-Muslim materials or discourses as their main subject of analysis, so as to determine whether some critics tend to attack a faith based on a set of precepts that are not found in $90 \%$ of its seminal book.

\section{Declaration of conflicting interests}

The authors declare no potential conflicts of interest with respect to the research, authorship, and/or publication of this article.

\section{Funding}

The first author of this study is since October 2015 supported by the KU Leuven internal research fund.

\section{References}

Abdel Haleem, M., 2005. The Qur'an: A New Translation. Oxford University Press, Oxford.

Abdel Haleem, M., 2001. Understanding the Qur'an: Themes and Style. Tauris, London-New York, I.B.

Abdul-Rahman, M.S., 2009. Tafsir Ibn Kathir Juz' 10 (Part 1), Al-Anfal 41 To At-Tauba 92. MSA Publication Limited, London.

Aly, A., 2016. Brothers, Believers, Brave Mujahideen: Focusing attention on the audience of violent jihadist preachers. Stud. ConflictTerrorism 731. http://dx.doi.org/ 10.1080/1057610X.2016.1157407.

Atwan, A.B., 2015. Islamic State: The Digital Caliphate. Saqi Books, London.

Ayatullah Kamal Al-hajj Sayyid Imani, 1991. An Enlightening Commentary into the Light of the Holy Qur'an, vol. 1: From Surah al-Fatiha (1) to Surah al-Baqarah (2) v. 154 (Volume 1, Vol. 1). Ahmadabad: The Scientific and Religious Research Center Amir-ul-Mu'mineen Ali.

Ayatullah Kamal Al-hajj Sayyid Imani, 1991. An Enlightening Commentary into the Light of the Holy Qur'an, vol. 6: From Surah al-A'raf (7) verse 88 to Surah atTawbah (9) (Vol. 6). Ahmadabad: The Scientific and Religious Research Center Amir-ul-Mu'mineen Ali.

Bastian, M., Heymann, S., Jacomy, M., 2009. Gephi: An Open Source Software for Exploring and Manipulating Networks. Third International AAAI Conference on Weblogs and Social Media 361-362. http://dx.doi.org/10.1136/qshc.2004.010033.

Bergsträßer, G., Pretzl, O., 1926. Die Geschichte des Qorāntexts. In: Nöldeke, T. (Ed.), Geschichte Des Qorāns (Zweite Auflage, Dritter Teil). Dieterichsche Verlagsbuchhandlung, Leipzig.

Bunzel, C., 2015. From Paper State to Caliphate: The Ideology of the Islamic State. Analysis Paper 19, 48. Retrieved from: https://www.brookings.edu/wp-content/ uploads/2016/06/The-ideology-of-the-Islamic-State.pdf.

Ciftci, S., 2012. Islamophobia and threat perceptions: explaining anti-Muslim sentiment in the West. J. Muslim Minority Affairs 32 (3), 293-309.

Conway, M., 2017. Determining the role of the internet in violent extremism and terrorism: six suggestions for progressing research. Stud. Conflict Terrorism 40 (1), 77-98. http://dx.doi.org/10.1080/1057610X.2016.1157408.

Donner, F.M., 2011. The historian, the believer, and the Qur'an. In: In: Reynolds, G.S. (Ed.), New Perspectives on the Qur'an Routledge, Oxfordshire - New York.

El-Badawy, E., Comerford, M., Welby, P., 2015. Inside the Jihadi Mind: Understanding Ideology and Propaganda. The Centre on Religion \& Geopolitics. London. doi:10.1017/CBO9781107415324.004.

Europol., 2016. European Union Terrorism Situation and Trend Report 2016. Retrieved from: https://www.europol.europa.eu/activities-services/main-reports/europeanunion-terrorism-situation-and-trend-report-te-sat-2016.

Fachrodin, A.A., 2015. The violent verses of the Qur'an in comparison between the classical and modern interpretations. Religió: Jurnal Studi Agama-agama 5, 1-25. ISSN 2503-3778, Retrieved from: http://religio.uinsby.ac.id/index.php/religio/article/view/52.

Feddes, A.R., Nickolson, L., Doosje, B., 2015. Triggerfactoren in Het Radicaliseringsproces. Rijksoverheid, Amsterdam Retrieved from: https://www.rijksoverheid.nl/ documenten/rapporten/2015/10/12/triggerfactoren-in-het-radicaliseringsproces.

Frissen, T., d'Haenens, L., 2017. Legitimizing the Caliphate and its politics: Moral Disengagement Rhetoric in Dabiq. In: Krishna-Hensel, S.F. (Ed.), Authoritarian and Populist Influences in the New Media. Routledge.

Fruchterman, T. M. J., Reingold, E. M., 1991. Graph Drawing by. Force-Directed Placement, In: Software-Practice and Experience, vol (21), 11, 1129-1164.

Gambhir, H. K., 2014. Dabiq: The Strategic Messaging of the Islamic State. Institute for the Study of War; Backgrounder. Retrieved from: http://www.understandingwar. org/backgrounder/dabiq-strategic-messaging- Islamic-state. 
Gendron, A., 2017. The Call to Jihad: charismatic preachers and the internet. Stud. Conflict Terrorism 40 (1), 44-61. http://dx.doi.org/10.1080/1057610X.2016. 1157406.

Hafez, M., Mullins, C., 2015. The Radicalization Puzzle: A Theoretical Synthesis of Empirical Approaches to Homegrown Extremism. Stud. Conflict Terrorism, 38(11), 958-975, doi:10.1080/1057610X.2015.1051375.

Hassan, H., 2017. Terrorists hijacked a single verse to justify their crimes. It's time to match their vigour. The National. Retrieved from: https://www.thenational.ae/ opinion/terrorists-hijacked-a-single-verse-to-justify-their-crimes-it-s-time-to-match-their-vigour-1.616340.

Holbrook, D., 2010. Using the Qur'an to justify terrorist violence : analysing selective application of the Qur'an in english-language militant islamist discourse. Perspect. Terrorism 4 (3), 15-28.

Imani Giglou, R., Ogan, C., D’Haenens, L., \& Van Gorp, B., 2014. Visualizing Online and Offline Networks of Turkish Diaspora in Three European Countries: Testing the Role of Network Structure and Dynamics in Social Capital Building, Using Evidence from the Gezi Park Protests in Turkey. In: ACM Web Science. Indiana, Bloomington.

Ingram, H.J., 2016. An analysis of Islamic State's Dabiq magazine. Aust. J. Political Sci. 1146 (June), 1-20. http://dx.doi.org/10.1080/10361146.2016.1174188.

Jacomy, M., Venturini, T., Heymann, S., Bastian, M., 2014. ForceAtlas2, a continuous graph layout algorithm for handy network visualization designed for the Gephi software. PLoS ONE 9 (6), 1-12. http://dx.doi.org/10.1371/journal.pone.0098679.

Lawrence, B.B., 2017. Muslim engagement with injustice and violence. In: In: Juergensmeyer, M., Kitts, M., Jerryson, M. (Eds.), Violence and the World’s Religious Traditions: An Introduction Oxford University Press.

Maher, S., 2016. Salafi-Jihadism: The History of an Idea. London: Hurst \& Co.

Maududi, S.A.A., 2006. Towards Understanding The Qur'an: Abridged version of Tafhim al-Qur'an. (Z.I. Ansari, Ed.). Leicester, UK.: The Islamic Foundation.

Meyer, E.D., 2017. Book review: Peter Sloterdijk. In the shadow of Mount Sinai. Polity. Philos. Rev. 37 (1), $30-32$.

Neumann, P., 2015. Foreign fighter total in Syria/Iraq now exceeds 20,000; surpasses Afghanistan conflict in the 1980s. International Centre for the Study of Radicalisation and Political Violence. Retrieved from: http://icsr.info/2015/01/foreign-fighter-total-syriairaq-now-exceeds-20000-surpasses-afghanistan-conflict1980s/.

Newman, M.E.J., 2006. Modularity and community structure in networks. Proc. Natl. Acad. Sci. 103 (23), 8577-8582. http://dx.doi.org/10.1073/pnas.0601602103.

Nöldeke, T., 1860. Geschichte Des Qorâns. Verlag der Dieterichschen Buchhandlung, Göttingen.

Novenario, C.M.I., 2016. Differentiating Al Qaeda and the Islamic State Through Strategies Publicized in Jihadist Magazines, Stud. Conflict Terrorism, 731(May), 0-15. https://doi.org/10.1080/1057610X.2016.1151679.

Rashid, Q., 2017. Anyone who says the Quran advocates terrorism obviously hasn't read its lessons on violence. Independent. Retrieved from: http://www.independent.co.uk/voices/islam-muslim-terrorism-islamist-extremism-quran-teaching-violence-meaning-prophet-muhammed-a7676246.html.

Reinares, F., García-Calvo, C., Vicente, Á., 2017. Differential association explaining Jihadi radicalization in Spain: a quantitative study. CTC Sentinel 10 (6), 29-34. Rudner, M., 2017. "Electronic Jihad ": the internet as Al Qaeda's catalyst for global terror. Stud. Conflict Terrorism 40 (1), 10-23. http://dx.doi.org/10.1080/ 1057610X.2016.1157403.

Saheeh International., 2004. The Qur'an (English Meanings), Jeddah.

Van Ostaeyen, P., 2017. An archive of Dabiq Magazine. Retrieved from: https://pietervanostaeyen.com/2015/04/24/the- Islamic-state-an-archive-of-dabiq-magazine/).

Von Behr, I., Reding, A., Edwards, C., Gribbon, L., 2013. Radicalisation in the Digital Era. The Use of the Internet in 15 Cases of Terrorism and Extremism. Brussels/ Cambridge: RAND corporation. Retrieved from: https://www.rand.org/pubs/research reports/RR453.readonline.html.

Wagemakers, J., 2015. The Concept of Bay'a in the Islamic State' Ideology. Perspect. Terror. 9.

Wignell, P., Tan, S., O'Halloran, K.L., Lange, R., 2017. A mixed methods empirical examination of changes in emphasis and style in the extremist magazines Dabiq and Rumiyah. Perspect. Terrorism 11 (2), 19.

Winter, C., 2015. The Virtual "Caliphate": Understanding Islamic State's Propaganda Strategy. Quilliam Foundation, July 2015.

Zelin, A. Y., 2016. A clearinghouse for jihādī primary source material, original analysis, and translation service. Accessible through: http://www.Jihadology.net.

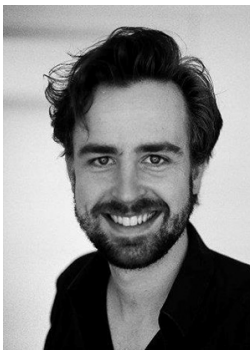

Thomas Frissen

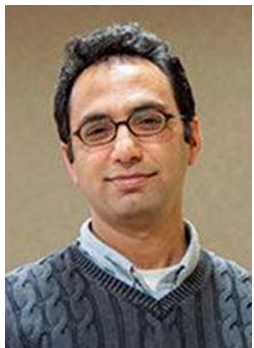

Erkan Toguslu 


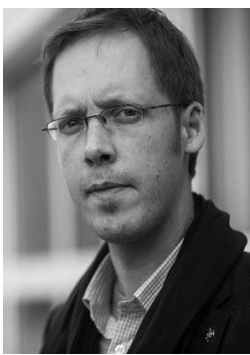

Pieter Van Ostaeyen

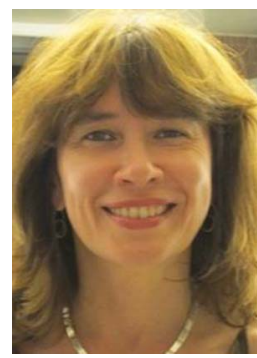

Leen d'Haenens 